Andile April

Postgraduate student,

Department of Journalism,

Tshwane University of

Technology, Pretoria,

South Africa

Email: Andile.april@sasol.

com

ORCID: http://orcid. org/0000-0002-1159-3628

Phillipine M. Maubane

Department of Journalism,

Tshwane University of

Technology, Pretoria,

South Africa

Email: Maubanepm@tut. ac.za

ORCID: http://orcid. org/0000-0002-9861-0151

Dr Lizette Odendaal

Department of Journalism, Tshwane University of Technology, Pretoria,

South Africa

Email: Odendaall@tut.ac.za (corresponding author) ORCID: http://orcid. org/0000-0002-7172-612X

DOl: https://dx.doi. org/10.18820/24150525/ Comm.v24.8

ISSN 2415-0525 (Online)

Communitas 2019 24: 1-17

Date submitted:

5 August 2019

Date accepted:

11 October 2019

Date published:

03 December 2019

(c) Creative Commons With Attribution (CC-BY)

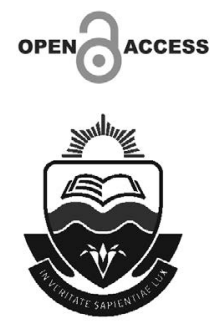

\section{EXPLORING KEY AREAS OF TRANSFORMATION IN A SOUTH AFRICAN MEDIA ORGANISATION}

\section{ABSTRACT}

Understanding the scope, progress and impact of transformation in the media industry in South Africa is important to ensure the success of its implementation. The impact of the digital revolution, the development of new media spheres and the subsequent information explosion brought new angles and variables to the transformation mix and created new challenges for transformative media managers. This study investigated perceptions of media transformation, transformation initiatives, and the extent of transformation activities at the Times Media Group for the period 1994 to 2016. Using the main themes of modernday media transformation as background to determine perceptions both from management and employees, the research identified areas of best practice, as well as areas of competitive weakness impacting on media management, media audiences and media practitioners. Qualitative data obtained from in-depth interviews and focus groups provided information on different types of media transformation, and the impact thereof on aspects such as ownership, management practices and media content. Results indicated a dedication and commitment to ongoing change and transformation by both media managers and practitioners. It provided valuable insight on how journalists' perceptions and media practices were impacted by transformation. Specific transformation themes were identified, which could assist media managers with change management processes and to implement meaningful business transformation.

Keywords: transformation; media transformation; media management; print media; digital innovation; online journalism; social media; media audiences; media displacement; media niche

\section{INTRODUCTION}

International trends such as liberalisation, socio-economic development, internationalisation and digitalisation continuously force change and transformation on democratic, societal and economic institutions. Additional to these international trends, political transformation since democratisation in 1994 had become an important change factor in South Africa. 
Transformation changed the way in which the South African society views itself, its interaction with democracy and its economic interaction as consumers and business markets (Manganyi 2004). The implementation of transformation policies and strategies on a national level affects all economic and government sectors and forces organisations to implement revised and new business practices to ensure equality and equity in the workplace and in economic society (Selby \& Sutherland 2006; Schoeman 2010). All industries are affected by transformation, with the media industry being no exception.

Over the past two decades, transformation has completely transformed the economic and business landscape of the country (Manganyi 2004). The main aim of transformation, as stated in the Constitution of the Republic of South Africa in 1996, was to achieve equitable representation in the workforce across occupational levels, industries and entrepreneurial enterprises (Alexander 2007). Transformational ideals were meant to improve the life of all South Africans, first by creating opportunities within organisations, and then by encouraging organisations to introduce corporate social responsibility initiatives that would empower and develop the historically disadvantaged South. In this way transformation in the workplace would filter through to improve the lives of citizens.

The first step in the transformation process was the drafting of a constitution for South Africa, followed by processes that would allow the new government to formulate clear and solid obtainable transformative projects (Heller \& Ntlokonkulu 2001). The next phase was to create economic opportunities for historically disadvantaged people to take part in the mainstream economy through employment and ownership opportunities in the corporate environment.

Central to the successful introduction of new policies and programmes on a national level, for any country, stands the role of the media. Leshin (2010) posits that the media have a unique role within the politics of transformation. Media organisations operate in dual positions - both as instruments of transformation and as sites of transformation. The media serves as change agents of transformation by providing essential platforms for communication and development between government, economic industries and society. Governments rely on the media to facilitate communication, introduce change, and persuade citizens to accept new ways of living.

But, as Daniels (2013) indicates, in order for the media to be successful agents of change, the media industry itself must believe in transformation principles and implement them within media organisations. The media as an industry was expected to transform itself according to the nationally prescribed policies and strategies. This resulted in major organisational change for the South African media industry, not only with regard to content and distribution, but also with important and crucial changes to business models (Casero-Ripollés \& Izquierdo-Castillo 2013). Upon realising the importance of a transformed media industry to the general success of transformation in South Africa, the government introduced several programmes, acts and bodies since the late 1990s to assist with expediting transformation within the media industry, with varying degrees of success. 
The success of transformation within the South African media industry has often been questioned, and in 2010 the ANC again called for an investigation into the challenges hampering the transformation of the print media industry. The government also mandated the development of a charter to deal with the concentration of ownership, language diversity and gender mainstreaming within the media industry (Daniels 2013). At its Mangaung policy conference in December 2012, the ANC confirmed that transformation, especially in the print media, remains a contested terrain and that real transformation is hindered by power struggles within the industry, as well as by ideological differences based on race, class and gender in society (ibid.).

In 2017, the Forum of Journalists for Transformation (FJT) indicated that there was still a general lack of transformation in the media and opined that role-players in the industry failed to acknowledge this fact (Mdluli 2017). De Beer et al. (2016) indicate that the role of the media in the new South Africa continues to cause intense debates. It is only when the industry itself is seen to have transformed that their messages and calls for transformation in the country will have credibility. De Beer et al. (2016) explain that this dilemma for the media is similar in all other new African democracies, and must be addressed to ensure the credibility of transformation processes.

The perception remains that transformation in the media has not been achieved in South Africa. Business Report (2016) reported that the ANC Women's League (ANCWL) called on the ANC-led government in 2016 to increase transformation efforts to support ownership, control and access to the media by historically disadvantaged communities. According to the ANCWL, 22 years after democracy, diversity and equity challenges in media organisations still impact on the objective dissemination of media content and impair the workings of successful media (Business Report 2016).

Leshin (2010) points out that the widespread disagreement among scholars and media practitioners about the success of transformation, or lack thereof, is indicative of the absence of a generally accepted definition of media transformation. Duncan (2016) agrees that different definitions exist, and posits that the one most widely used is by Boloka and Krabill (2000 in Duncan 2016): "Successful transformation is achieved when the elements of society, i.e. race, socio-economic status, gender, religion, language and culture is reflected in the media industry in terms of its ownership, staffing and the product".

With the advent of online technologies and internet journalism, transformation challenges increased and media managers had to implement even more change processes. Duncan (2016) notes that modern transformation weaknesses lie in the disappearance of in-depth reporting due to time constraints caused by media inequalities, income dependencies and the fragmentation of audiences. The pressure on media organisations to transform is evident, but to add to these significant changechallenges is the context of technological innovations and the rise of the internet and social media (Casero-Ripollés \& Izquierdo-Castillo 2013). The influence of online and social media causes strong competition for media income and leads to huge decreases in the revenue of print media products, thus decreasing the resources available for transformational and developmental programmes. 
The need for descriptions of and information on media transformation in South Africa is clear. Different opinions, views and outlooks on the concept of media transformation exist. These opposing views from within the industry complicate the creation of yardsticks by which transformation progress can be measured. It also creates confusion about what a complete, pragmatic approach to transformation management should, and should not, include. Any change management or transformation process relies heavily on resources and therefore needs to be accurate to create a competitive advantage for media managers and organisations.

\section{BACKGROUND}

\section{Modernisation theory}

The modernisation paradigm applies insights from communication models to address the shortcomings of development and modernisation in developing countries (Mowlana \& Wilson 1990; McConnell \& Servaes 1995). With the emergence of disruptive technologies during the second half of the 20th century, developing countries had to deal with new technological challenges, which compounded the existing political and economic issues (Conradie \& Diederichs 2012).

The aim of the modernisation approach is to assist developing countries to change according to the example of developed countries in terms of critical factors such as economic systems and production, political structures, the transfer of information and communication technologies, urbanisation, social and cultural life, ideology and communication systems (Mowlana \& Wilson 1990). In South Africa, after 1994, all of these key factors were influenced by transformation - impacting on the development process of the country.

This study indicates that it is because of the responsibility of communicating change and transformation to large parts of South Africa that the pressure on the media to transform itself is so intense. According to the modernisation theory, the South African media should be responsible for developing and transforming the society, and for developing and transforming itself.

\section{Displacement theory}

The media displacement theory focuses on the displacement effect of technological change and development on traditional media (De Waal \& Schoenbach 2010). The displacement theory assumes that when a new medium enters the media industry it impacts negatively on existing media forms by providing new opportunities for news consumption for current users (Newell et al. 2008).

Vyas et al. (2007) explain that in a post-modernist media world displacement effects influence all traditional media forms as the old media increasingly lose their audiences to the internet, and therefore lose valuable advertising revenue (Napoli 2010). Dimmick et al. (2004) concur that, with increased competitive displacement, all media forms are in competition with each other. 
By using the media displacement theory as a second lens, this study investigates the print media industry in South Africa, as displaced both by socio-political development and by new media technologies. This displacement leaves media organisations with no other option, but to transform and restructure their business processes and operations, to ensure economic growth and survival.

\section{Theory of niche}

The theory of niche provides an understanding about how different media forms and organisations compete and co-exist in limited resource environments for economic survival (Dimmick 2002; Okazaki et al. 2009). From this perspective, the comparative ability of a news organisation to fulfil audiences' needs and to provide them with gratification is imperative for its survival.

One way of doing this, as part of business transformation, is by implementing new media content solutions in utilising internet access and creating online presence (Vyas et al. 2007). The South African media industry is characterised by limited resources and ongoing political change, adding to the displacement of traditional media. Leshin (2010) indicates that private and public media institutions need to transform by redefining their niche markets (traders, advertisers, staff and owners) in terms of transformational directives.

The theory of niche indicates that traditional media need to transform and re-invent their niche areas in order to survive. Indicative to this study, the drivers of this niche transformation in South Africa include socio-political pressure, on the one side, and technological development, on the other side. Using the theory of niche, this study determines the impact of transformation practices and change management processes on the creation of new niche areas.

\section{Business transformation}

In order to create economic equity in a country, business transformation is the most important element of any transformation process. Kaplan and Norton (2004) describe business transformation as a strategy of change management that aims to successfully link people, processes and technology with the organisation's strategy and vision.

Norris (2001) points out that any successful organisational transformation must be part of a wider strategic initiative, which intends to bring about significant modifications in institutional management and practices. Norris (2001) explains that change in the business world is mostly unplanned, referring to the political, economic, socio-cultural or technological changes to which managers must respond with transformational change for their businesses to adapt. This process compels managers to intentionally re-engineer organisational structures, tasks and relationships to adjust to change and to enable the organisation to stay competitive.

The importance of transforming organisations in order to transform the country has been pointed out since the early days of transformation in South Africa. The original transformation policies and practices implemented by the government alone did not do much to transform the business world in South Africa (Jacobs 2002). Economic 
industries had to take this legal mandate further and implement transformation practices suited to each industry.

\section{Media transformation}

On the one hand, the media are the protected providers of a public service and uphold democracy, while on the other hand, they are private businesses selling products. As private businesses, they have to adhere to the same transformational policies that they advocate to the public. According to the market model, the media should be treated like all other commercial businesses and be held to the same regulations. This concept is supported by media management scholars (Compaine \& Gomery 2000; Keeble 2006) who emphasise that newspapers are primarily businesses that exist to make money and, in doing so, they meet people's informational needs.

The media industry in South Africa came under government scrutiny during the late 1990s, at the height of workforce transformation and affirmative action. Pressure on the print media industry to appoint black media practitioners paid off. Berger (2001) indicates that by 2000 , nine of the large dailies in South Africa had replaced white editors and deputy editors with black appointments. However, none of these appointments included women. According to Bhorat and Goga (2012), while in 1994 there was not a single black woman in a managerial position in any South African media company, in 1999 , black women held at least held six percent of the managerial posts in the media.

The South Africa media industry has witnessed countless transformation approaches, practices and activities since 1994. But, in the early 2000s most first-line managers were still English-speaking, younger men, with good educational credentials (Steyn \& De Beer 2004). Duncan (2016) indicates a lack of female representation in media management structures in South Africa, with males dominating at senior levels, such as section heads in investigative units. It is clear that there is the will to implement transformation practices, but intention alone does not automatically result in meaningful, substantial and continued change.

\section{RESEARCH METHODOLOGY}

This phenomenological study followed a qualitative inquiry strategy to explore the key areas of media transformation in South Africa. By using a South African media organisation, Times Media Group (TMG), the perceptions of both management and employees on the phenomenon of transformation were explored.

Purposive sampling was used in order to collect data for this study. Because the aim of the study was to explore key areas of transformation in a large South African media organisation by determining the views of both management and employees, empirical data was collected through two qualitative data methods. In-depth interviews were conducted with managers and executives at TMG, as more insight was sought for a managerial perspective on the concept of transformation.

Secondly, the focus group method was used with working journalists at TMG to provide them with an opportunity to express their feelings and viewpoints on transformation 
in the organisation. Each focus group consisted of between six and ten professional journalists, stationed at various newspaper agencies of TMG. The participants had more than five years' media experience and their ages ranged from 25 to 40 .

A thematic data analysis was used in this study to analyse the themes that emerged from the data results. These themes were further explored and analysed to form the proposed key variables of media transformation at a South African media organisation.

\section{FINDINGS}

In order to establish a conceptualisation of the variables that will be influenced by or impact on the construct of media transformation, it was important to determine how participants from within the industry viewed media transformation. In determining a mutual understanding of the concept, all the respondents agreed that transformation should bring about fundamental and effective change, not only in product, audiences and distribution, but also resulting in efficient organisational change processes that will cascade into societal and cultural change.

Concepts become measurable when theoretical definitions are measured against operational implications and pragmatic processes (Papastefanou 2008). Therefore, to bring order and structure to the data and to foster an understanding of the different variables affecting transformation activities, empirical data is presented according to identified themes. These themes were selected according to thematic analysis, used in exploratory studies, and served to explain existing perceptions and information with regard to transformation at TMG.

\section{Theme 1: Ownership and management}

One of the first transformational goals in South Africa post-1994 was for organisations to include the representation of black people at executive board level. This goal was to ensure that blacks, as business owners, would fundamentally be involved in the implementation of operational and strategic decisions to ensure that transformation filtered through to all lower levels, as well as the community.

Results indicate that TMG was one of the first media organisations in South Africa to introduce ownership changes through take-overs, mergers or joint ventures with the aim to diversify to black ownership. Each of these ownership changes impacted on the organisational culture and media outputs of professional journalists.

The respondents voiced criticism at the fact that ownership and management changes happened "too often" and without clear corporate communication to senior staff members about the implications. The respondents questioned the long-term effectiveness of these ownership changes as part of a transformation goal, and felt that it slowed down the organisation's growth because of the disruptive nature of change. The general perception was that ownership changes merely benefitted a black elite, and did not provide Black Economic Empowerment (BEE) opportunities to general employees.

The research findings indicated that the advantages of having new owners included the availability of corporate funds for equipment, and new business contacts, which 
could be used for securing advertising. The main disadvantage of frequent ownership changes appeared to be the creation of a "distance" between owners and workers. Both the managers and the journalists felt that the new owners only had their own financial interests at heart, rather than true transformational objectives.

Continued ownership changes in media groups are in line with global patterns where horizontal integration of media titles by media groups leads to the creation of monopolies in media markets (Franklin 2008). Criticism includes that changes in ownership patterns inhibit audience choice, dictate content and content patterns (Meyer 2004), and inhibit diversity, quality and journalistic freedom (Franklin 2008).

\section{Theme 2: Business transformation}

No single measure exists to measure transformation in the media industry, and as indicated by Daniels (2013), BEE scorecards have stopped indicating success in overall transformation. Transformation success can only be achieved if business industries transform, resulting in opportunities for staff, customers and target groups. For the purpose of this study, the term business transformation was selected as a theme to clarify transformational changes that impact media business processes. These include advertising, as main income source; audiences, as consumers of media products; and operational technology, which indicates the changing nature of journalists' jobs.

\section{Advertising}

Advertising and access to advertising is always one of the first agenda points at any media transformation meeting. For a declining print media industry (Swanepoel 2012), in light of the internet and social media, advertising approaches needs to be re-invented.

The staff members at TMG all realise the importance of advertising as a main income source, and understand the threat of digital media to print media advertising. The quick pace of development of multimedia platforms necessitate constant change in the way advertising at TMG is managed. Senior managers re-strategise and transform their approach to advertising and new advertising business models are created with a focus on advertorials and other initiatives to augment advertising income.

One of the advertising initiatives is the implementation of native or sponsorship advertising in order to generate revenue. This is a type of advertising, mostly online, that matches the form and function of the platform on which it appears, but produced by an advertiser, which will then promote a specific product. The difference is that it is not seen as an advertisement as such, but it is presented in a similar form and style, and it is generally seen as the work of the platform's editorial staff. The term "native" refers to this coherence of the advertising content with that used by the online platform. This is a form of paid for media content.

The latest income threat to news organisations, as indicated by the results, is the search engine Google. Corporate businesses are spending significant amounts of money trying to reach customers via advertising through Google news searches. Many news consumers search for breaking news stories directly on Google, instead of using 
regular news media. Through advertising linked to these news reports, Google makes money out of the searches and none of this money filters down to the media houses, such as TMG, which produce the original articles in the first place. With Google being an international company, this advertising revenue is lost to South Africa.

De Waal and Schoenbach (2010) refer to the displacement effect that new technologies have on traditional media and recognise the dire implications for advertising income. The results also indicated that more innovative ways of creating advertising income were constantly explored by TMG. The managers and the journalists agreed that this was an important item of discussion in all meetings and forums.

\section{Audiences}

Napoli (2010) indicated that modern media audiences have unprecedented choice between different technologies, platforms and devices for their consumption of news content. The results confirmed that, in line with this, the readership profiles of news audiences at TMG had changed. From the interviews, the managers indicated that the socio-economic, political and consumption profiles of their traditional target groups had changed beyond recognition over the past years. TMG's audience now represent the black middle class, younger mobile-oriented users, and traditional readers who prefer to read print titles online.

Digital innovation significantly influences the news consumption patterns of audiences. This new audience marketplace allows media users total choice, and it affords them the opportunity to become producers and distributors of content themselves on social media. The journalists indicated that this change required news "around the clock and on the move", and for TMG to stay relevant it had to "merge news platforms and create a super newsroom", operating 24 hours per day. This led to product innovation (inclusion of graphics, visuals, colour and movement), changed distribution channels and the inclusion of content generated by users. For the first time, TMG now breaks stories on online platforms and then follows up in print news titles with in-depth stories.

Social media has led to younger audiences preferring different types of news stories. Rather than reading long, investigative articles, they want short, headlinetype newsflash stories, written in simple words and phrases. For the journalists to satisfy this new need, they had to learn how to adapt and write copy for social media platforms, such as Facebook and Twitter.

The findings on the transformation of audiences at TMG and the fragmentation of the media market have definite implications for the handling of news audiences. Napoli (2010) agrees that changed audiences will impact traditional news markets and predicts that media audiences will continue to evolve in response to this. At TMG, this reality became a strategic objective and the organisation, as far as audience change is concerned, has become a learning organisation that accepts continued change.

\section{Operational technology}

The occupation of being a journalist has forever transformed with globalisation of the internet and the development of online technologies (Saldaña et al. 2017). 
The respondents confirmed that modern journalists have to cope with very strict deadlines, must maintain social closeness with their readers and audiences, and must adapt to changed work processes to include multitasking and adaptability. The results in this study indicated that it was indeed technological change that served as the main driver for transformed journalism practices, as well as the rising financial cost of operations.

The respondents indicated that the immediacy and 24-hour availability of news on online and mobile platforms had forced TMG's management to adapt operations. The journalists had to be given access to social media and had to create official social media accounts on Facebook and Twitter. This implied that new talent had to be recruited to manage the social media platforms and the journalists had to learn how to report for, and on, social networking sites. TMG was forced to re-examine its online content distribution strategies and TMG journalists were no longer confined to their desks, but were able to file stories from anywhere using laptops provided by the company. News diary sessions are conducted electronically and journalists are able to record their interviews with news sources instead of "writing on notepads". However, expensive technology has to be replaced constantly to keep up with developments and to ensure the relevance of news presentation in the way it is gathered, interpreted and consumed. TMG now also makes use of innovations, such as Uber, for journalists in order to save money in terms of vehicles' maintenance, insurance and petrol costs. However, as TMG is a large company, many of the respondents felt that not all journalists at all publications benefitted equally.

The new operational technology also impacts on the expected productivity of journalists, as well as their ability to constantly improve their knowledge and technology skills. The journalists indicated that they had to be at the forefront of technology and that those who refused to adopt ICT did so at their own peril, no matter their current profile or status. To complicate their daily work further, cost-cutting measures prevented reporters from building relationships with news sources, conduct investigations, or visit news scenes. Therefore, the journalists saw themselves as desk journalists who were forced to source stories online and then still had to ensure objective quality in content presentation.

\section{Theme 3: Human resources transformation}

As the concept of transformation centres around human resources in the workplace, and how changes impact employees, this dynamic is central to any transformational change. Sudden or constant change brings adaptive and disruptive working conditions with increased pressure on leaders to implement change and manage changed work environments (Hannah et al. 2011).

\section{BEE practices}

BEE was an integral part of transformation in South Africa. During the in-depth interviews, the managers attested to the fact that TMG was one of the first media companies to embrace BEE as a practice. Through these initiatives, black-white staff quotas had been achieved. The majority of the respondents indicated that blacks were increasingly being appointed into editorial positions at TMG's different titles, but 
that the authority linked to these positions was limited. This was one of the reasons provided for the lack of sustainability in transformative positions at TMG because the power to make decisions, often editorial, remained with those who had moved up to the boardrooms.

In principle, TMG embraced the concept of BEE and focused on creating an equitable, fair employee profile - especially in the lower ranks, for example, the newsrooms. Many affirmative action appointments have taken place and, according to the professional journalists, newsrooms now represent the South African community.

As with any change management process, the implementation of BEE at TMG led to a temporary transition period with a loss of skills, but according to the respondents, stability had returned. BEE created space for younger journalists who replaced the older generation. The younger journalists did more work for lower salaries, and adopted faster to a multi-skilled environment with a higher production output.

Criticism from the respondents indicated a need that BEE at TMG should also lead to the economic empowerment of both individual employees and the business community. In their choice of business partners and suppliers, it was indicated that TMG was not doing enough to ensure black economic empowerment for its business communities. Moreover, the journalists pointed out that although BEE appointments had been made at TMG, this led to no financial gain or economic empowerment of the employees in terms of shares ownership, profit sharing, or performance incentive bonuses.

\section{Women empowerment}

Women empowerment as part of transformation in South Africa's economic sector is still a contested and topical issue. This is similar elsewhere in the world where in a modernist, global media industry the role and impact of women is researched and debated (Gouws 2008).

The respondents in this study indicated that evidence of women empowerment at TMG in terms of female journalists being promoted to editors did exist. To date, a number of female journalists were promoted to news editors and editorship roles for different TMG newspaper titles, for example Sunday World. Women empowerment is regarded as a key transformational area in the organisation, but a lingering concern is the sustainability of these positions. A challenge for TMG was that promoted women did not seem to remain in the positions, and a lack of support and development initiatives by TMG to empower female appointees were indicated as possible reasons.

There had been a definite increase in women appointed in more junior reporting positions, but very few women were represented in ownership and management structures. The findings indicated that TMG did not have a formal woman empowerment programme to assist with succession planning, career advancement, or management potential development. The female respondents voiced their concern that in the true sense of empowerment, women were not empowered at TMG. They mentioned as examples pay inequality, the allocation of soft reporting beats, and the lack of empowerment projects. 


\section{Skills development}

With media production as its core function, skills development is considered important at TMG. The respondents affirmed the management's commitment towards constantly identifying skills gaps, providing plans and implementing actions to develop journalistic skills.

TMG also has a Journalism Training Programme, which was established in 1998 to help create a pool of predominantly black journalists with the knowledge and skills necessary to be appointed in available affirmative action positions. Regular courses and training are provided by TMG to improve media skills in order to ensure a quality media product. The respondents also named the "job coaching" programme, where supervisors would provide mentorship both with regards to journalism tasks, and management/leadership skills, as one of TMG's successful programmes. Criticism, on the other hand, included the perception that TMG's transformation activities were just done in order for the management to be able to report to the government, and to complete the "BEE tick boxes".

The responses showed that TMG invested time and money in skills development and committed to lifelong learning. However, these initiatives were limited to journalistic skills and the perception existed among staff members that it was more for the product's sake than for transformational staff development purposes.

\section{Theme 4: Digital transformation}

The concept of global digitalisation has transformed the media industry by presenting completely new ways of transmitting information. Not only did it change the profile of audiences (De Waal \& Schoenbach 2010), with implications for content production, but it also displaced traditional print media (Newell et al. 2008) forcing newspaper organisations to adapt their product in numerous ways. All of these global tendencies were confirmed by the results in the study; also impacting on the change and transformation processes of TMG.

\section{Content change}

TMG was forced to implement content change in line with changed audience requirements. The respondents indicated that TMG stayed relevant to its new audiences by making news simpler; thus, creating usable products. The product was used to uplift and educate readers, especially when journalists investigated the performance of the government.

The editors of the different TMG publications have also made concerted efforts to cover stories that appeal to the average news consumer. Newspaper titles, such as Sunday World and Sowetan, have introduced business reporting sections written in more simplified, plain and understandable language for a broader readership.

Competition from social media has forced TMG titles to be innovative and adopt social media as part of their content distribution strategy. A further implication of this new trend was that TMG had to adapt their content from a hard news approach to a 
softer news approach, similar to news feeds that digital audiences see daily on social networking sites. This new "celebrity-style" news content is what readers prefer.

Content packaging at TMG also changed completely; this was where the skills development of the journalists played a major role. The journalists had to re-package the same content (story) for different media platforms. Content, in this sense, does not refer to only a news story, but to a packaged production, which includes text, audio, sound, pictures, web links and video. The journalists had to change their perception on news content, and how it should be produced.

\section{The impact of language}

The results also indicated that digital transformation influenced the use of language in two ways. Firstly, the journalists now had to write for a wider, more diverse audience. Secondly, they had to adapt the language usage of their online reporting to appeal to a new digital generation of media users.

The language usage in the newspaper titles had to be simplified and the newspaper content became more accessible and reader-friendly. This meant that the different newspapers had to relax their style rules, and embrace the language preferences of their transformed audiences. This language transformation was, and is, reflective of the demographics of the country.

Both the managers and the journalists further acknowledged the huge influence that new media platforms and social media had on the use of language in news reports. To report on news that had already been seen on social media demanded a new phraseology, as well as fresh angles and approaches. The respondents indicated that the journalists were trained to use concise language, which was in line with social media posts.

TMG is committed to adaptive language usage as part of transformation, and the journalists indicated that they regularly attended courses focusing on the difference between print and online platforms in terms of reporting, and on using language innovatively. They journalists further explained that not only was the shortened version of writing stories a skill to be learnt, but social media had its own terminology and acronyms. Twitter journalism, for example, demands new language skills, and TMG newspaper titles, which are active on social media platforms, adapted to this style of writing to retain competitive niche advantage.

\section{Digital and online platforms}

The influence of social media on newsrooms and journalists has been unprecedented in how news is gathered and distributed (Govender-Bateman 2018). The respondents agreed that the development of multiplatform journalism influenced every area of TMG's daily management and functioning.

At first, TMG only started with an internet website where news would be covered. This website, TimesLive, was one of the first online news websites in South Africa, and it still exists. After TimesLive, TMG expanded to include different publications such as SowetanLive and Sunday World. 
The introduction of social media led to the different publications establishing their own social media pages with handles advertised in the printed versions. All newsrooms in the group have been digitised and the new challenge is to keep up with software development and new interfaces. The last development in digital business transformation was the incorporation of Facebook and Twitter into the news delivery platforms.

The respondents explained that TMG also had to adapt its management style to embrace social media. TMG management now made use of ICT to improve communication in the newsrooms. Mobile technology ensured that editors could get hold of reporters at any location, and get a story immediately. In addition, time is saved by digital transformation. TMG reporters file stories at any time via the internet or mobile technology, and record visuals with their cellular phones. Moreover, organisational communication benefitted as management and editors are able to communicate instantly with groups of employees and reporters via platforms such as WhatsApp.

In terms of news distribution, TMG has become an online first media group where news is first covered online, and then in print media. As part of this digital strategy, and to counter declining print readership, TMG print news stories are promoted using social media platforms and Twitter handles. Other positive benefits of digital innovation include closer and faster interaction with readers, cheaper online distribution and new marketing channels. The journalists who were interviewed also confirmed that TMG was increasingly equipping them for the challenges of multi-platform journalism and therefore empowering them to become digital reporters.

\section{CONCLUSION}

The study conceptualised the dual purpose of the print media within the broader transformation of South Africa, and focused on both political and business transformation. By identifying areas of best practice and areas for improvement at TMG, the research aimed to determine the extent to which transformation had been achieved at the media organisation.

Qualitative data obtained from in-depth interviews and focus group interviews provided information on different types of media transformation, and the impact thereof on aspects such as ownership, management practices and media content. It further provided valuable insight on how journalists' perceptions and media practices were affected by transformation.

The findings indicated that media transformation was not prompted only by political change, but also by digital development, changed audience habits, media displacement and media competition. Although the perceptions on specific aspects of successful transformation differed, there was agreement that transformation practices and policies should lead to development, both for the industry and for media practitioners.

Based on the findings, the study proposed important trends and key variables that could contribute to a new interpretation and possible definition of media transformation in the modern media. The results showed a symbiotic relationship between all of these transformation variables and indicated that transformation should be measured as an 
integrated, systematic approach that addresses all four main transformation themes. The themes could be used to build an integrated transformation management model, by which transformation initiatives can be implemented, monitored and measured.

The research also suggested that print media organisations should employ effective internal communication strategies to include employees in transformation and change programmes and obtain buy-in. In an increasingly competitive media industry, print media organisations need to stay relevant and competitive to retain media audiences. In this regard, the findings from this study could provide guidelines to media managers to evaluate transformation practices and to use the key variables of modern media management in the development of successful change management plans.

\section{REFERENCES}

Alexander, N. 2007. Affirmative action and the perpetuation of racial identities in post-apartheid South Africa. Transformation: Critical perspectives on Southern Africa 63(1): 92-108. https://doi.org/10.1353/trn.2007.0013

Berger, G. 2001. De-racialization, democracy and development: Transformation of the South African media 1994 - 2000. Media democracy and renewal in Southern Africa 151-180.

Bhorat, H. \& Goga, S. 2012. The gender wage gap in the post-apartheid South African labour market. Journal of Economic Growth 12(1): 211-252. https://doi.org/10.2139/ ssrn. 2184258

Business Report. 2016. Dismantle white-owned print media - ANCWL. [Online]. Available at: https://www.iol.co.za/business-report/companies/dismantle-white-owned-printmedia-ancwl-2084584 [Accessed on 10 November 2016].

Casero-Ripollés, A. \& Izquierdo-Castillo, J. 2013. Between decline and a new online business model: The case of the Spanish newspaper industry. Journal of Media Business Studies 10(1): 63-78. https://doi.org/10.1080/16522354.2013.11073560

Compaine, B.M. \& Gomery, D. 2000. Who owns the media? New York: Lawrence Erlbaum. https://doi.org/10.4324/9781410605368

Conradie, D.P. \& Diederichs, P. 2012. Using the information needs of internet users in combating disruptive innovations in the newspaper industry. Communitas 17(1): 1-20.

Daniels, G. 2013. State of the newsroom. South Africa, disruptions and transitions: A research report by WITS Journalism. [Online]. Available at: www.journalism.co.za/ docs [Accessed on 10 October 2016].

De Beer, A., Malila, V., Beckett, S. \& Wasserman, H. 2016. Binary opposites - can South African journalists be both watchdogs and developmental journalists? Journal of African Media Studies 8(1): 35 - 53. https://doi.org/10.1386/jams.8.1.35_1

De Waal, E. \& Schoenbach, K. 2010. News sites' position in the mediascape: Uses, evaluations and media displacement effects over time. New Media \& Society 12(3): 477-496. https://doi.org/10.1177/1461444809341859

Dimmick, J.W. 2002. Media competition and coexistence: The theory of the niche. New York: Routledge. https://doi.org/10.4324/9781410606211 
Dimmick, J., Chen, Y. \& Li, Z. 2004. Competition between the internet and traditional news media: The gratification-opportunities niche dimension. The Journal of Media Economics 17(1): 19-33. https://doi.org/10.1207/s15327736me1701_2

Duncan, J. 2016. Transformation of media content. Presentation at Print Media Transformation Colloquium, Freedom Park. South Africa.

Franklin, B. 2008. The future of newspapers. Journalism Studies 9(5): 630-641. https:// doi.org/10.1080/14616700802280307

Gouws, A. 2008. Changing women's exclusion from politics: Examples from Southern Africa. African and Asian Studies 7(4): 537-563. https://doi. org/10.1163/156921008X359650

Govender-Bateman, RS. 2018. New opportunities for news dissemination: The use of twitter journalism at a news agency in South Africa. Unpublished Master's dissertation. Tshwane University of Technology, Pretoria, South Africa.

Hannah, S.T., Avolio, B.J. \& Walumbwa, F.O. 2011. Relationships between authentic leadership, moral courage, and ethical and pro-social behaviors. Business Ethics Quarterly 21(4): 555-578. https://doi.org/10.5840/beq201121436

Heller, P. \& Ntlokonkulu, L. 2001. Civil Society Project: The South African National Civic Organization. Johannesburg: Centre for Policy Studies.

Jacobs, S. 2002. How good is the South African media for democracy? African and Asian Studies 1(4): 279-302. https://doi.org/10.1163/156921002X00033

Kaplan, R.S. \& Norton, D.P. 2004. Strategy maps: Converting intangible assets into tangible outcomes. UK: Harvard Business Press.

Keeble, R. 2006. The newspapers handbook. New York: Taylor \& Francis. https://doi. org/10.4324/9780203012772

Leshin, M. 2010. Writing change: Affirmative action as a tool for newspaper transformation at the Durban Post. Global Media Journal - African Edition 4(1): 51-72. https://doi. org/10.5789/4-1-12

Manganyi, N.C. 2004. Gerard Sekoto: 'I am an African': A biography. Johannesburg: Witwatersrand University Press.

McConnell, J.J. \& Servaes, H. 1995. Equity ownership and the two faces of debt. Journal of financial economics 39(1): 131-157. https://doi.org/10.1016/0304405X(95)00824-X

Mdluli, A. 2017. Forum of Journalists for Transformation (FJT) sceptical about transformation in media industry. Transform SA - the Quarterly Journal for a Transforming Nation. [Online]. Available from: http://transform sa.co.za.

Meyer, P. 2004. The influence model and newspaper business. Newspaper research journal 25(1): 66-74. https://doi.org/10.1177/073953290402500106

Mowlana, H. \& Wilson, L.J. 1990. The passing of modernity: Communication and the transformation of society. UK: Addison-Wesley Longman. 
Napoli, P.M. 2010. Audience evolution: New technologies and the transformation of media audiences. New York: Columbia University Press.

Newell, J., Pilotta, J.J. \& Thomas, J.C. 2008. Mass media displacement and saturation. The International Journal on Media Management 10(4): 131-138. https://doi. org/10.1080/14241270802426600

Norris, P. 2001. Digital divide: Civic engagement, information poverty, and the Internet worldwide. UK: Cambridge University Press. https://doi.org/10.1017/ СBO9781139164887

Okazaki, S., Li, H. \& Hirose, M. 2009. Consumer privacy concerns and preference for degree of regulatory control. Journal of Advertising 38(4): 63-77. https://doi. org/10.2753/JOA0091-3367380405

Papastefanou, N. 2008. Management in virtual organisations. Unpublished doctoral thesis. Tshwane University of Technology, Pretoria, South Africa.

Saldaña, M., Higgins-Joyce, V.D.M., Schmitz-Weiss, A. \& Alves, R.C. 2017. Sharing the stage: Analysis of social media adoption by Latin American journalists. Journalism Practice 11(4): 396-416. https://doi.org/10.1080/17512786.2016.1151818

Schoeman, N. 2010. The drivers and restraining factors for achieving employment equity at management level in gold mining companies. Unpublished doctoral thesis. Gordon Institute of Business Science, University of Pretoria, South Africa.

Selby, K. \& Sutherland, M. 2006. Space creation: A strategy for achieving employment equity at senior management level. South African Journal of Labour Relations 30(2): 42-65.

Steyn, E. \& De Beer, A.S. 2004. The level of journalism skills in South African media: A reason for concern within a developing democracy? Journalism Studies 5(3): 387-397. https://doi.org/10.1080/1461670042000246124

Swanepoel, T. 2012. A comprehensive quality management model for community newspapers. Unpublished doctoral thesis, North West University, Potchefstroom, South Africa.

Vyas, R.S., Singh, N.P. \& Bhabhra, S. 2007. Media displacement effect: Investigating the impact of internet on newspaper reading habits of consumers. Vision 11(2): 29-40. https://doi.org/10.1177/097226290701100205 